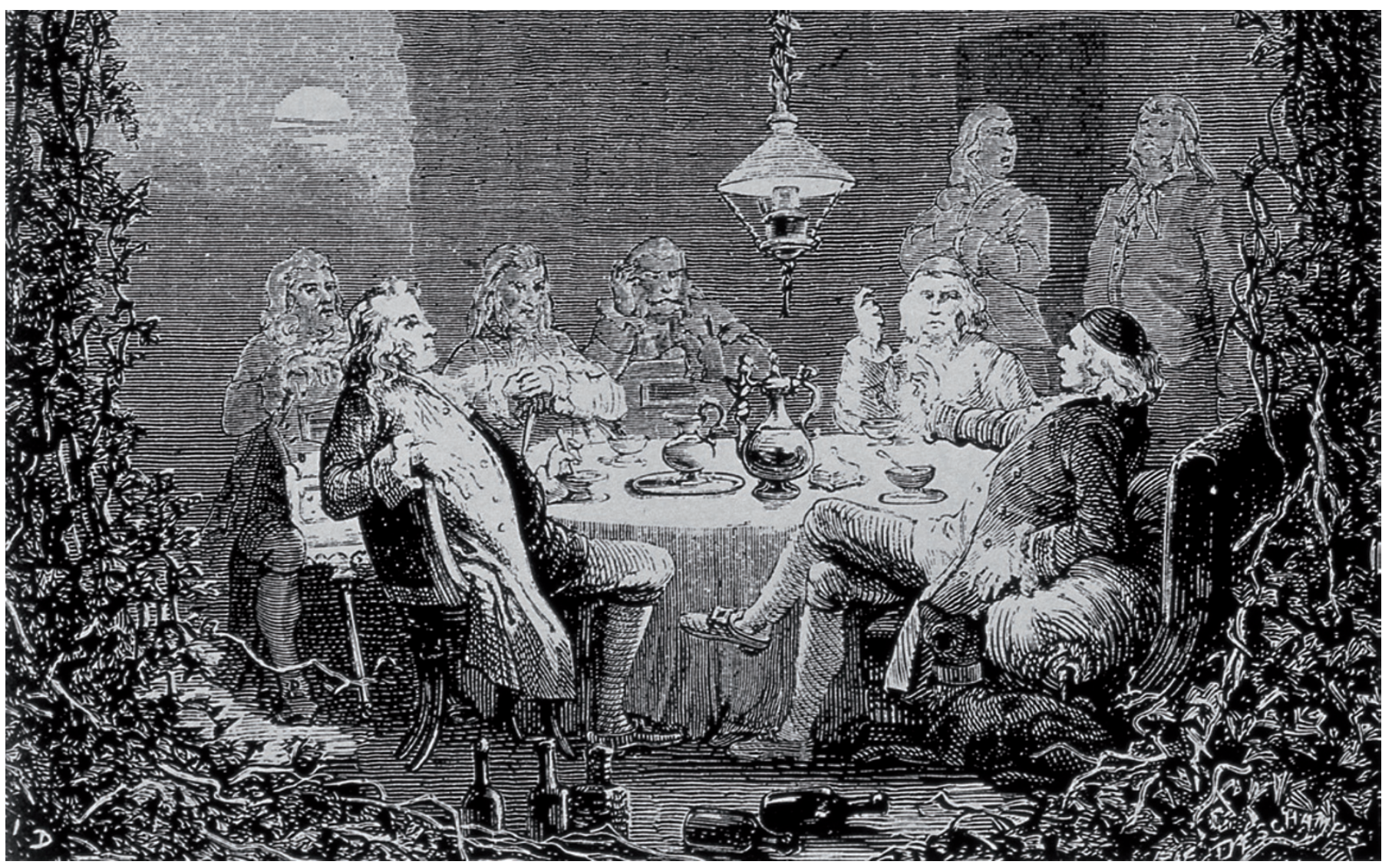

Erasmus Darwin was a prominent member of the Lunar Society, which met monthly to discuss science, politics, art and philosophy.

\title{
HISTORY
}

\section{Darwin the eroticist}

\section{William Bynum applauds a life of physician and scientific poet Erasmus Darwin, Charles's intriguing grandfather.}

$\mathrm{P}$ eter Medawar shared a Nobel prize in 1960 for his work on acquired immunological tolerance. But perhaps his best-known work was his 1963 essay 'Is the Scientific Paper a Fraud?' This was not concerned with plagiarism or data falsification: instead, the great biologist was drawing attention to the fact that the finished, published version of scientific research generally presents the paths to the conclusions as simple, logical and smooth. Authors omit the false dawns, failed experiments, discussions with colleagues over coffee or beer, and the many contingencies that almost always accompany a piece of research.

Patricia Fara sets all that complexity centre stage in Erasmus Darwin: Sex, Science and Serendipity, her study of the medical doctor, poet, philosopher and abolitionist Erasmus Darwin (1731-1802), grandfather of Charles. Fara leads the reader along the often bumpy trail of her historical research into the life and work of this many-sided man, her attempts to understand his difficult poetry, and her gradual placement of him in the political and social context of his time.

We follow her as she goes into rare-book rooms, gets stuck in foreign airports, buys facsimile copies of works by Erasmus Darwin and his contemporaries, remem-

bers old trips to museums and tries to make up for her lack of a classical education. (Her undergraduate degree was in physics.) This is not so much a book about Darwin as a book about writing a book about him.
Fara uses this conceit, she tells us, to help readers to appreciate how historians actually work. She uses no impersonal third-person sentence structure of the kind Medawar identified with the scientific paper. So we get sentences such as "I once found myself in a bizarre tourist trap", or "When you get stuck in a research project, one rescue tactic is to let your mind relax and wander about freely". It keeps her narrative flowing and it does portray pretty accurately the ways casual as well as systematic - in which historical research and writing emerge.

Embedded in Fara's self-conscious account of her project is a convincing study of Erasmus Darwin. When he is not entirely forgotten historically, he often has only a walk-on part in accounts of the life of his remarkable grandson. There is also a tradition, stretching back to Samuel Butler's Evolution, Old and New (1879) arguing that all of Charles's major ideas - artificial and 
natural selection, sexual selection, adaptation and biological evolution itself — had already been advocated by Erasmus, and that Charles owed much more to his grandfather than he ever admitted.

Fara is less concerned with the relationship of grandfather and grandson than with situating Erasmus Darwin in the history of ideas, and in understanding his poetry. His scientific poems, The Loves of the Plants, The Economy of Vegetation and The Temple of Nature, gave the Lichfield physician a reputation both at home and in Europe.

The first two of these (combined in 1791 to form The Botanic Garden) were published during the early years of the French Revolution. Their advanced social and political ideas - such as criticism of slavery - and their perceived erotic content attracted controversy. In Britain at that time, anything smacking of the 'revolutionary' stirred up fears lit by the fires across the Channel: Darwin's friend, the chemist and Unitarian minister Joseph Priestley, published widely on radical issues at the time, and had his house burned down by an anti-French mob. He fled to the United States.

So what of Darwin's poems? In many ways, they are simply ardent celebrations of Britain's industrial achievements, along with fruity expositions of the sexual system on which Linnaeus based his classification of plants. To eighteenth-century sensibilities they seemed arousing - even lines such as "A hundred virgins join a hundred swains/And fond ADONIs leads the sprightly trains". That daring was compounded by Darwin's espousal of biological change through time, his liberal ideas on the evolution of human society, his appreciation of many things French, and his assignment of God to the position of remotely initiating the cosmic process, but taking no further part in its unfolding.

Erasmus Darwin is most commonly seen in association with Priestley, James Watt, Josiah Wedgwood and other members of the Lunar Society. This informal group of industrialists, medical men, inventors and natural philosophers met monthly (by the light of the full Moon) to discuss topics such as the latest discoveries in pneumatic chemistry and ways of building a better steam engine.

Fara explicates both these classical and contemporary reverberations in Erasmus Darwin's writings. She invites modern readers to take him and his ideas seriously, not simply as a relative of the great Charles, but as a substantial figure in his own right. In this she triumphantly succeeds, even while admitting that she doesn't like his poetry. It is not difficult to see why.

William Bynum is professor emeritus of medical history at University College London, UK.

e-mail:w.bynum@ucl.ac.uk

\section{Books in brief}

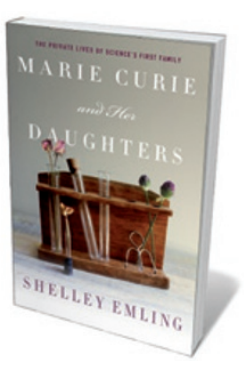

Marie Curie and Her Daughters: The Private Lives of Science's First Family

Shelley Emling PALGRAVE MACMILLAN 256 pp. £16.99 (2012)

The blazing trajectory of Marie Curie the scientist has left the private woman in the shadows. Shelley Emling delves into the last 20 years of Curie's life, reframing her as mother and humanitarian. The often harrowing tale covers the great physicist's struggle with xenophobia and sexism, her mental and physical breakdowns, and the campaign by American journalist Missy Meloney to supply her with radium. Most compellingly, it bares Curie's relationships with her daughters, the Nobel prize-winning chemist Irène and writer Eve.

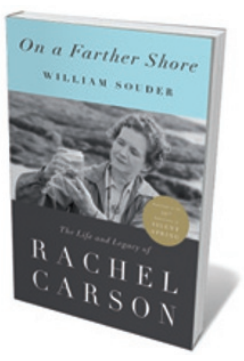

On a Farther Shore: The Life and Legacy of Rachel Carson

William Souder CRown 544 pp. £19.99 (2012)

It is 50 years since biologist Rachel Carson's Silent Spring appeared in book form, following serialization in The New Yorker. This paradigm shift in the way we think about the environment, and the sensitive and searching intelligence behind it, make for a many-layered story eloquently told by William Souder. Carson's pull towards science and development as a writer are explored, and Souder picks his way through the polarized reactions to her book. Acceptance of Carson's warnings on the misuse of pesticides such as DDT was widespread, but protestations from industry and others persist to this day.

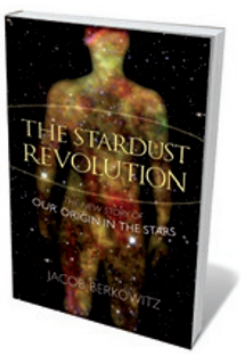

The Stardust Revolution: The New Story of Our Origin in the Stars Jacob Berkowitz PROMETHEUs 312 pp. £23.95 (2012)

Having set out to write a book on the nexus of evolutionary biology and astronomy, physics writer Jacob Berkowitz ended up at 'extreme genealogy'. We might inherit brown eyes or big bones, but we also carry a heritage from the stars - chemical bonds and cell molecules. Berkowitz is an amiable tour guide: starting with astrochemist Lucy Ziurys's radiotelescope tracking of oceans of molecules pooled across the Milky Way, he finishes in open-ended style at the search for Earth-like planets. In between, he tacks back and forth through the history of astrobiology to entertaining effect.

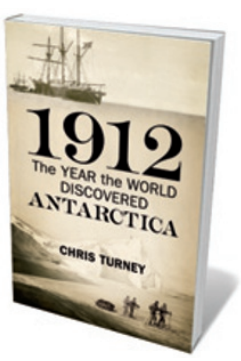

1912: The Year the World Discovered Antarctica

Chris Turney BODLEY HEAD 368 pp. £20 (2012)

A century on, the exploits of 'golden age' explorers in Antarctica still grip us. The expeditions of Robert Falcon Scott, Roald Amundsen and Douglas Mawson are oft-told tales, but in this engaging treatment by climate scientist Chris Turney, the forays of Japan's Nobu Shirase and Germany's Wilhelm Filchner get an airing too. The portraits are nuanced. Shirase's crew both bag key geological findings and hunt penguins out of boredom - while Filchner's team, trapped by sea ice on the Deutschland, first set up a magnetic observatory in record time, then rapidly succumb to drunken mayhem.

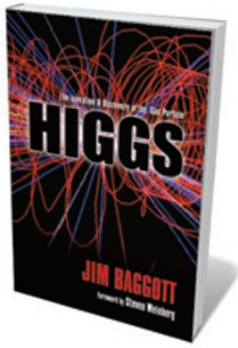

Higgs: The Invention and Discovery of the 'God Particle' Jim Baggott OXFORD UNIVERSITY PRESS 304 pp. £14.99 (2012) Science writer Jim Baggott gives the lowdown on a showdown one of the biggest in science. The Higgs boson or 'something very much like' it emerged at CERN in Geneva on 4 July, and Baggott chronicles the science leading up to that moment, threaded through with the stories of the main players, from Emmy Noether to Peter Higgs. A foreword by theoretical physicist Steven Weinberg, a useful glossary, and a tendency towards brevity and clarity make for a handy guide to the long hunt for an elusive quarry. 